\title{
シンポジウム(7) 遠隔医療の近未来像
}

\author{
司会のことば \\ 小島 博己 \\ 東京慈恵会医科大学 耳鼻咽喉科 \\ 川䇏 良明 \\ 川产耳鼻咽喉科
}

ICT 技術の進展とAI 機器の進歩は目覚ましく、その応用は日常診療の中にも入ってきている。遠隔医療は「通信技 術を活用した健康増進、医療、介護に資する行為（日本遠隔医療学会2011）」と定義され、さらに「通信技術を活用し て離れた 2 地点間で行われる医療活動全体を意味する」とされる。海外では「患者の健康状態を改善するために電気通 信により伝送された医療情報を利用すること（American Telemedicine Association）」としている。

わが国に㧍ける遠隔医療の社会的背景には、少子高齢化（高齢者に対する経済的・効率的な医療の要求)、医師不足 と偏在、過疎地・離島の問題などに加えて医師間のニーズ（専門医への相談）があげられる。また画像診断や病理診断 など遠隔医療のいくつかは自宅でも行うことが可能であり、女性医師の増加や働き方改革対策としても期待できる。

医師法第20条はいわゆる無診察診療の禁止を詔っているが、厚生労働省はオンライン診療の重要性からこれを容認す る方針に転じ、平成30年 4 月から診療報酬上にも「オンライン診察料」が新設された。今後 ICT の飛躍的進歩により さらに拡大していくものと考えられる。

このような状況下で、眼科に扔いてはすでに細隙灯顕微鏡を専門医の遠隔操作によって患者を診察することが可能と なり、皮虐科では病変部を肉眼より鮮明に拡大表示したりすることも行われつつある。すなわち専門医が近くにいない 地域に㧈いて遠隔医療による専門医の开ポートがなされるようになっている。またリアルタイムで生体モニタリングを することも可能になっている。遠隔聴診は慢性疾患のフォローアップ目的のほかに肺炎や喘息発作の発症などの判断に 有用な情報を提供できるし、リアルタイム生体モニタリングは在宅医療や遠隔妊婦健診、救急医療などへの活用が期待 される。ダヴィンチは現在最も普及した手術支援ロボットであるが、元々はアメリカ陸軍が軍用に開発を依頼したもの であり、遠隔操作で戦場の負傷者に対して必要な手術を行うことが目的とされている。

このように遠隔医療が進歩した背景には近年の著しい IT 機器および通信環境の改善の貢献が非常に大きい。固定回 線ではADSLやケーブルテレビの導入が進み、光ファイバーに移行したことで急速に大容量化が実現された。またモ バイル回線は $3 \mathrm{G} 、 4 \mathrm{G}$ と進化し、デー夕伝送速度が指数関数的に向上し、固定ネットワーク、モバイルネットワークと もにあらゆるデータが瞬時に共有可能な状況になり、PC、タブレットやスマートフォンなどで手軽に鮮明な動画をス ムーズに送受信できるようになってきている。5Gではさらに「超高速」「超高信頼・超低遅延」「超多数接続」の 3 つ の特長を上手に組み合わせることで、 $4 \mathrm{G}$ 世代に比べ20倍もの高速化が実現され、 $4 \mathrm{~K} や 8 \mathrm{~K}$ といった高精細な動画デー

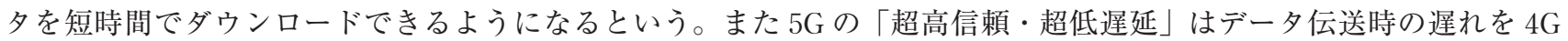
に比べて $1 / 10 に$ 抑えることにより遠隔治療に大きく貢献できると考えられる。このような進歩に加え近い将来は触覚 などの情報伝達も可能になると思われ、対面診療と遠隔診療の質的な差が縮まることは間違いない。このような背景を もとに本シンポジウムでは 4 名のエキスパートにご講演いただく。

まず基調講演として株式会社 NTT ドコモ $5 \mathrm{G}$ イノベーション推進室担当部長の奥村幸彦様に「5G が変える医療一地 域医療、救急医療から高度医療に至る幅広い領域における $5 \mathrm{G}$ 遠隔診療の実現に向けて一」と題した $5 \mathrm{G}$ の特長を活か した医療ソリューションについてご講演をいただく。次に東京慈恵会医科大学教授の鴻 信義先生には「教育システ ム・国際交流」と題し、Web 会議システムによるカンファレンスおよび手術支援・教育システムなどについてご紹介 いたたくく札幌医科大学耳鼻咽喉科教授の高野賢一先生には「遠隔医療を用いた難聴者（児）の総合支援システム」と して人工内耳装用者を対象とした遠隔マッピング、遠隔言語訓練の抒話を伺う。そして山下診療所自由が丘／大塚理事 長の山下 䉷先生からは「オンライン診療 臨床現場での遠隔医療の実践」として、遠隔診療に扔ける舌下免疫療法と CPAP の管理について括話を伺う予定である。

ICT から AI、IoT、ビッグ・データなど新しい技術や考え方が次々に開発され、医療も大きな時代の変化を迎えてい る。本シンポジウムを通して遠隔医療の最前線に触れていただくことにより、皆様方に大きな知恵とヒントを与えてく れると確信している。 


\section{基調講演 5G が変える医療 一地域医療、救急医療から高度医療に至る 幅広い領域における $5 \mathrm{G}$ 遠隔診療の実現に向けて一}

奥村 幸彦

株式会社 NTT ドコモ 5Gイノベーション推進室

次世代移動通信システムである第 5 世代移動通信システム（5G）は、経済成長に不可欠な IoT(Internet of Things) 時代の ICT 基盤として早期の実現、ならびに普及・展開が世界的に期待されており、各国・各地域においてその実用 化と商用導入に向けた動きが加速している。さらに、5G は、超高速・大容量通信、超高信頼・低遅延通信、多数同時 接続などの特長を持ち、それらを活かした多様な新サービス・アプリケーションの創出活動も活発に行われている。特 に医療分野への応用においては、地域医療、救急医療から高度医療に至るまで幅広い領域を対象として5Gの特長を活 かした医療ソリューションの実現が期待され、ドコモにおいても遠隔診療のしくみを取り入れたそれらソリューション の検討および実証を推進している。

いわゆる「遠隔医療」は、情報通信機器を活用した健康増進、医療に関する行為全般を言うが、その実現および導入 促進は、限られた数の医師または医療機関を有効に活用して、より広いエリアでの医療サービスの提供を可能とするも ので、医師や医療機関の不足や偏在と言った問題を解消するための重要な方策の一つである。この遠隔医療のうち、医 師一患者間（D to P) において、情報通信機器を通して、患者の診察および診断を行い診断結果の伝達や処方等の診療 行為を、リアルタイムにより行う行為を「オンライン診療」と呼んでいるが、さらに高度な遠隔医療として近年注目さ れているのが医師一医師間（D to D）において、情報通信機器を通して、患者の診察および診断、ならびに治療を行 う行為（本講演において「遠隔診療」と呼ぶ）である。この遠隔診療では、患者と同じ場所（診察室）にいる医師に対 して、遠隔地にいる専門医（経験豊富なべテラン医師）が通信回線を介して伝送された各種診断情報を参照しながらア ドバイスや支援を行うが、その際、専門医が離れた場所にいることを意識せず、あたかも同じ診察室内にいるかのよう な環境を再現して診療を進められことが重要となる。各種診療科で用いられる医療機器のうち、特に画像または映像を

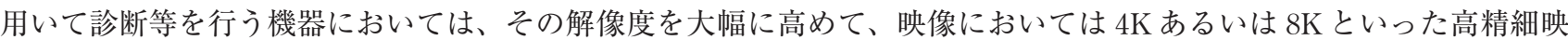
像を用いることにより、正確かつ詳細な診断が可能となる。また、診療科または対象となる疾患の種類によっては、即 時性を求められるケースがあり、画像・映像情報をリアルタイムに参照できるようにすることも必要となる一方、複数 の医療機器からの画像・映像情報を組み合わせて診断するケースもある。さらに、医療機器からの画像・映像情報に加 えて、患者の様子や容体を遠隔地にいる医師が把握しやすくできるカメラ映像が有用であるとともに、医師間のコミュ ニケーションをスムーズに行うためのテレビ会議システムが有用である。このテレビ会議システムの映像も $4 \mathrm{~K}$ などの 高精細映像とすることで、臨場感のある映像により意思疎通を行いやすくなるとともに、上述した患者の様子や容体を 遠隔地にいる医師が把握するための映像を兼ねることもできる。

上述した診断用の高精細画像・映像やカメラ・テレビ会議映像を遠隔地に一括して伝送するためには相対的に容量の 大きい通信回線が必要であるため、これまで遠隔診療における通信回線としては、一般に固定（有線）通信ネットワー クを用いることが想定されていたのに対し、超高速・大容量通信、超高信頼・低遅延通信が可能な $5 \mathrm{G} の$ 登場により、 移動（無線）通信ネットワークを積極的に用いて、遠隔診療サービスの提供または利用できる場所と機会を拡大するこ とが可能になる。なお、遠隔診療の通信回線として $5 \mathrm{G}$ を適用する箇所は、患者のいる診察室（固定または移動の医療 施設）側へのアクセス部分のみならず、遠隔地からアドバイス・支援を行う専門医側へのアクセス部分も考えられ、こ の場合、専門医が出張先からアドバイス・支援することにも対応可能となる。

ところで、昨今、世界的に社会課題となっている新型ウイルス感染症への医療対応の現場においては、感染患者（ま たは感染の疑いのある患者）への専門医による迅速かつ正確な診療が求められる一方で、副次的な感染のリスクを低く 抑えることも重要となるため、このような状況下では、物理的な接触を回避可能な通信ネットワークを介した遠隔診療 のしくみが有用であると期待される。

本講演では、ドコモにおける $5 \mathrm{G}$ の商用導入に向けた取り組み概況を述べた上で、5G を活用する遠隔診療に着目し、 地域医療の充実に向けた $5 \mathrm{G}$ の活用事例、救急搬送の高度化に向けた 5G の活用事例、5G を搭載する次世代移動診療車 をべースとしたモバイル診療ソリューション等について、それぞれのコンセプトと実証試験・模擬試験の実施状況を紹 介する。 
教育システム・国際交流

\author{
鴻信義 \\ 東京慈恵会医科大学 耳鼻咽喉科
}

近年、インターネット環境や関連機器が飛躍的に発展した結果、パソコンやサーバー同士が接続されるだけでなく、 スマートフォンやタブレット端末も接続され、文字はもちろん静止画・動画、音声・音楽などさまざまな情報がリアル タイムで双方向性に行き交うようになった。国境をまたいだ国際的なコミュニケーションも、インターネット環境さえ 整っていれば容易である。

われわれはインターネットを活用した教育の一環として、Web 会議システムを用いて教室内カンファレンスを開催 している。カンファレンスは大学敷地内の会議室で開催され、原則として教室員全員に参加が求められる。しかし実際 は、遠方の関連病院に勤務している、あるいは入院患者のケアなどで関連病院内から出られないなどの理由で、会議室 に参集できる教室員の数は全教室員の半分にも満たない状況であった。これをWeb 開催としたことで、各関連病院内 のパソコンや個人のタブレット端末などを通してカンファレンスに参加できるようになり、参加者数が増加した。カン ファレンスでは画像検討、症例報告、抄読会、予演会などを中心に、会場にいなくても手術時の動画や画像所見、検査 所見などを閲覧しながらディスカッションできる。特に、診断や治療に戸惑った症例を報告し、その過程で得られた知 見や反省点を共有できることは、比較的小さい組織内で行うカンファレンスの利点の一つだ。上級医からの莫大な臨床 経験に基づくコメントも重要で、EBM とは異なる視点で Personalized Medicine（個別化医療）の基にもなる。今後 は、カンファレンスで提示されたさまざまな医療情報を、時代ごとのアーカイブスとしてネットワーク上の記録装置内 でライブラリ化することで、生涯学習の効率もより向上すると期待している。

当院ではそのほか、患者の画像や手術室映像などを職員用スマートフォンで閲覧しグループ内で共有できる。例えば 緊急な対応が必要な患者の治療内容などのデイスカッションやアドバイスは、若手医師にとってインパクトの強い教育 ッールになり得る。

遠隔医療の一つとして、インターネットを活用した手術支援・教育システムも今後の発展が期待できる分野だ。例え ば内視鏡下鼻副鼻腔手術の術中画像を音声とともにリアルタイムで配信することで、アプリケーションをパソコン内に ダウンロードしておけば、手術室外のどこにいても手術の閲覧が可能だ。また、双方向性の意見交換はもちろん、画面 上に矢印や文字を書き込める上書機能（アノテーション）を使えば、あたかも指導医がすぐ隣にいるような環境下での 手術も可能となる。手術画像や音声は、インターネットを通して海外へも配信できる。東南アジアなどの開発途上国に 対しては、逆に現地で施行されている手術を日本に配信してもらい、その画面上でアノテーション機能を使いながら指 導することも可能だ。現状は、開発途上国でのインターネット環境がまだ十分なレベルに達していないこともあり、配 信される画質の低下や通信の断裂などに悩まされるが、今後環境は改善されていくだろう。このような手術指導という 形での国際交流は、トラブル発生時の対応などクリアしなければならない課題もあるが、将来的に IoTや人工知能 （AI）と組み合わされ、術野の位置情報や患者の生体情報などをふまえたより安全で的確なものになると考える。 


\title{
遠隔医療を用いた難聴者（児）の総合支援システム
}

\author{
高野 賢一 \\ 札幌医科大学 耳鼻咽喉科
}

近年の通信機器・通信技術の進歩は目覚ましく、医療分野に扔いても遠隔医療の有用性があらためて注目されてい る。遠隔医療は、患者のアクセスビリティの向上、地域による医療資源差の解消、勤労世代の労働時間確保などの諸問 題を解決できる可能性がある手段のひとつとして考えられ、2018年度からはオンライン診療料が保険収載されている。 広大な面積を有する北海道では、医療機関へのアクセスビリティが常に問題となっており、大学病院などの専門医療機 関から離れた地域に在住する人工内耳装用者にとっても、遠方からマッピングもしくは訓練目的に定期的に通院するこ とが時間、費用、身体的負担となっていることも少なくない。実際、われわれが継続してフォローアップしている300 人超の装用者のうち、約半数は札幌市以外に在住しており、札幌市内・近郊在住の装用者に比べ、それ以外の地域の装 用者は通院頻度が半分程度となっている。そこでわれわれは、人工内耳装用者を対象とした遠隔マッピング、遠隔言語 訓練を開始している。遠隔マッピングの対象となるのはコクレア社製 N6、N7、KANSO の装用者であり、現在は道内 4 都市（带広、函館、室蘭、八雲）に限定している。遠隔言語訓練は、札幌から遠方または近郊でも通院が難しい、構 音・構文が未習得である小学生を対象としている。具体的には、各地方の中隔医療機関の耳鼻咽喉科外来に専用端末 （Windows PC）を設置し、大学病院とインターネット回線を介して Nucleus Fitting Software(NFS) を遠隔操作してマ ップ調整を行う。遠隔操作はTeamViewer を使用し、コミュニケーション（ビデオチャット）はオンライン診療システ ム CLINICS（メドレー社）を使い、回線や端末の負荷を軽減するためNFS と CLINICS 用端末を分けている。事前に インターネット接続を地方病院側のスタッフが行い、装用者は設置された 2 台の端末前に座り、用意された説明書と大 学病院側の言語聴覚士からの説明を受けながら、ワイヤレスプログラミングポッドを自身のプロセッサに接続し、マッ プ調整を実施する。遠隔言語訓練は同じくCLINICS を使用するが、大学病院側の PC と自宅のスマートフォンやタブ レットと繋いで定期的（月 2 回、1 回あたり 30 分間）に実施している。遠隔診療で最も肝要なのは円滑なインターネッ 卜接続であり、事前の通信環境整備と予行に意外と労力を割いたが、確立されればその後はスムーズである。ワイヤレ スプログラミングポッドの接続は、装用者自身で行ってもらうが、手元に用意してある写真入りのマニュアルを見なが ら行うことで、比較的容易にできている。マッピングに関しては、NFSは通常のマッピングソフト (CustomSound 5.1）と仕様が異なり、書き込み可能なマップの数に制限があるものの、インピーダンスの測定、主音量や TCレベル の調整が可能で、調整時間も短時間である。対面に近い形で機器の状態が確認できるため、マップ調整に加えてメンテ ナンスの相談なども合わせて行うことができる。遠隔マッピングのよい適応としては、装用 1 年以上が経過した比較的 聴取が安定している装用者で、年齢としては㧍拉む小学生以上であれば問題なく行える。複数のマップを使う装用者 や、個々の電極の調整ができないため顔面㾏攣が出る装用者には不向きだが、将来的にNFSがアップデートされれば 適応となるだろう。遠隔言語訓練では、端末の前に一定時間着座できる児童であれば、対面式と比べ遜色なく訓練を実 施できている。マッピングと異なり、保護者のスマートフォンやタブレットを使用するため事前の準備は難しくなく、 画面や音声も良好である。言語訓練はマッピング以上に通院頻度が多く、保護者の就労などで時間的制約があるケース では、在住地域にかかわらず需要があり、実際に大学病院通院圈内であっても遠隔言語訓練は好意的に受け入れられて いる。今回使用している CLINICS の利点として、文字チャットが可能なこと、4G 環境下においても対面式に近い形で 装用者もコミュニケーションがとれること、将来的に遠隔リハビリ等に保険点数がついた場合に対応できることなどが 挙げられる。われわれが進めている遠隔支援は患者の高い満足度が得られており、現時点では法整備や診療報酬などの 課題が残されているものの、耳鼻咽喉科領域も含めて患者志向医療として今後ますます発展していく可能性がある。 


\title{
オンライン診療＼cjkstart臨床現場での遠隔医療の実践
}

\author{
山下嗾 \\ 法山会 山下診療所自由が丘／大塚
}

ICT の進歩と普及を遠隔医療に活用することで、医療へのアクセスが改善し、あるいは医師の偏在や過重労働が改善 することが期待されている。

五感を駆使する対面診療に比して、オンライン診療では視覚・聴覚に限定されることから、収集する情報が減少す る。ビデオ越しの二次元画面では General Impression として表現される患者さんの元気度や「何かおかしい」といっ た感度も下がるため、厚生労働省が作成した「オンライン診療の適切な実施に関する指針」では新しい疾病の診断には オンライン診療でなく対面診療で行うことが求められている。一方海外では、家庭での診察キットとして外耳所見や咽 頭所見などを画像化する精度の高いデバイスの開発が進んでいる。

診療行為は、診察・検査・処置・手術・処方などいくつかの要素で構成されているが、指導・管理といった部分はオ ンライン診療に親和性がある。慢性疾患の場合、治療が長期にわたるため適切な指導・管理が診療の大きな部分を占 め、継続通院や服薬アドヒアランスが治療のカギとなる。継続診療の阻害因子である通院コストを下げることがオンラ イン診療では可能となる。

耳鼻咽喉科領域で慢性疾患の指導・管理が大きな比重を占める分野として、アレルギー性鼻炎に扔ける舌下免疫療法 や睡眠時無呼吸症候群におけるCPAP の管理などがある。舌下免疫療法は2018年の保険改訂の際には残念ながらオン ライン診療の保険適応から漏れてしまったため、臨床現場での有用性の検証が困難となった。当院では保険収載される 前後でのテキストチャットやオンラインで遠隔医療を実施した患者の治療継続率を調查した。グラフから示唆される要 素を検討したい（図）。

アプネアモニターから得られる睡眠状況は、問診や対面時の診察では得られない患者の日々の情報を含んでおり、管 理する医師が参照するのみならず患者自身も生活習慣のフィードバックに活用できるデータである。同様に IoTを活用 したウエアラブルデバイスの進歩により、診察間を埋める日常のさまざまな身体情報を収集することが可能になってい る。

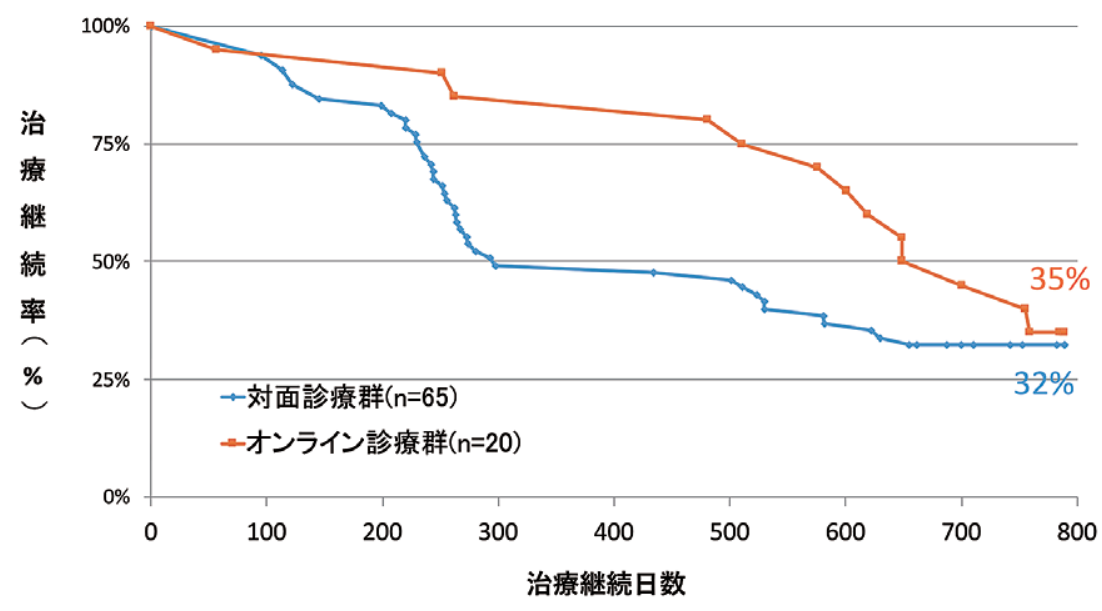

